MATEC Web of Conferences 48,06005 (2016)

DOI: $10.1051 /$ matecconf $/ 20164806005$

(C) Owned by the authors, published by EDP Sciences, 2016

\title{
Active learning approach in Moodle for the organization of student's self-study practice-based learning activities
}

\author{
Veronica Ivanova $^{1, a}$, Kseniya Mertins ${ }^{1}$, Mariya Abdrashitova ${ }^{1}$, and Dariya Isaeva ${ }^{1}$ \\ ${ }^{1}$ National Research Tomsk Polytechnic University, 634050 Tomsk, Russia
}

\begin{abstract}
Nowadays e-learning tools and delivery methods have been constantly expanding. Employs use e-learning to train their employees more often and often. New and experienced employees have the opportunity to improve upon their knowledge base and expand their skill sets. At home, individuals are granted the access to the programs that provided them with the ability to earn online degrees and enrich their lives through the expanded knowledge. The paper focuses on the analysis of the advantages and disadvantages of e- learning. The ways of applying on-line training used by employers are demonstrated. The experience of implementing active methods of e-learning is described as well as the conclusion about the possibility of their application is made. The paper also presents the results of the survey conducted among TPU teacher and students concerning the advisability of e-learning usage.
\end{abstract}

\section{Introduction}

The current stage of the development of active training methods is characterized by the increasing distribution of interactive training technologies. Distinctive features of active and interactive training are reflected in the way of organizing the interaction of the teacher and students. The main way of interaction becomes not only active feedback between the teacher and students, but also interaction of students among themselves. The main functions of the teacher have changed - the teacher acts more as an organizer and an assistant, collaborative learning in small groups becomes the main form of training.

Modern telecommunications technology allows students and teachers to support a constant "live" (interactive) dialogue with a real partner, and makes it possible to communicate in real-time.

E-learning environment has changed the delivery methods of training materials as well as the character of interaction among the participants of the educational process. In different models of elearning the share of tasks performed in the conditions of direct contact "face to face" between a teacher and a student decreases. This fact influences the choice of teaching methods.

The educational environment, in which e-learning is carried out, is interactive by its nature. It is the Internet with its great opportunities for creation and transfer of educational content, the organization of interaction and cooperation. It allows teachers to find and choose the most appropriate tools and technologies by means of which it is possible to apply methods of active training in teacherled training sessions and in the on-line environment.

\footnotetext{
${ }^{\mathrm{a}}$ Corresponding author : kurator@tpu.ru
} 
Communication activities (e-mail, forums, conferences, on-line blogs, etc.) and exploration activities (mainly navigation of contents) are required by e-learning. These activities can be found in a Learning Management System (LMS). LMS is a platform for administrating, documenting and delivering e-learning contents, which offers the enrolled students a vast number of courses with high customizability. Many of these platforms, such as Moodle, Sakai, Docebo, Atutor, Ilias, LRN, etc., are increasingly used in schools and universities as a powerful support and improvement for teaching activities [1].

According to [2], using Moodle platform improved professor-student communication and increased students' satisfaction with their courses.

\section{Methodology}

Theoretical and empirical methods of research are applied for identifying the main regularities and productive achievements which can be further implemented into teaching practice. The following types of students' activities are used: observation, experiential learning, pedagogical documents analysis, studying the products of students' educational and creative activity, on-line surveys.

\section{Results and discussion}

\subsection{On-line learning systems: advantages and disadvantages}

Nowadays, there are a lot of disputes on the issue of on-line learning introduced to technical students (power engineering, space device engineering, electronic engineering, etc.). On the one hand, people supporting cutting-edge technologies distinguish their advantages which are mainly concerning their unlimited options and possibilities. On the other hand, there are quite a lot of people who single out more negative aspects in organizing self-study work using on-line learning, in particular in Moodle system. Let us carry out the analysis.

The main advantages of e-learning are the following. Firstly, there is no limitation in time and location. It implies that a student can study at any suitable time and place. Secondly, a student has the opportunity to ask the teacher questions in e-learning environment, particularly online. More than $30 \%$ of students expect their teacher's assistance and support. Moodle as an element of university elearning environment allows the teacher to provide informational and conceptual support of the module. Thirdly, passing various tests and completing tasks in e-learning environment, students have the opportunity to obtain the results of their training, analyze their gaps in tasks as well as to study again the issues difficult for understanding. Fourthly, it is the way of realizing teacher's creative potential: Moodle allows including interactive and active teaching methods in the educational process (almost $40 \%$ of students expect an interesting way of presenting material): video lectures, creative tasks, tests, etc.

To the disadvantages we can refer the following: the necessity of available devices with the Internet connection as well as the situation when one cannot be sure that the task was carried out by the student individually without anybody's help. The obtained on-line experience is purely theoretical by nature. Besides, the development of students' communication skills can become complicated as the teacher does not always apply the active and interactive technologies.

During the educational process, the undergraduate's objective is to obtain the skills that would meet their future employer's requirements to the full extent. Nowadays, e-learning is becoming more and more popular among different companies. In terms of access, cost, function, online learning can be tailored in compliance with business needs. About $80 \%$ of employers often use technologies for training, retraining and professional development of their employees. New and experienced workers alike now had the opportunity to improve upon their industry knowledge base and expand their skill sets [3]. 
E-learning is beneficial to employers in many ways. Companies save between $50 \%$ and $70 \%$ of a budget when they replace an instructor-based training with e-learning. Training with e-learning refers courses delivered into shorter sessions and spread out over different days. It improves productivity, as employees no longer need to travel or get in rush-hour traffic to get to a class [4].

Empirical studies show that e-learning technology has positive effects on learning effectiveness and job performance as well. Furthermore, e-learning technology plays an important role in facilitating learning content and interacting with learners in organizational learning [5].

An increasing number of companies is relying on learning technology to boost their business forward. Towards Maturity Benchmark Survey shows that $72 \%$ of the 600 companies surveyed, claim that learning technologies helped their businesses adopt more quickly to change [4].

\subsection{Description of the using experience}

The increase in applying active and interactive teaching methods in e-learning environment has been already described above. Now we should consider the application of "Mind Maps" for organizing students' self-study work.

Mind Mapping is a method of capturing information created by Tony Buzan. It is believed that Mind Map can be applied to every aspect of life where improved learning and clearer thinking will enhance human performance.

For the purpose of designing tasks applying the method of Mind Maps, such Moodle tools as Seminar or Forum can be used. Applying these tools, the work performed by a student is evaluated by their fellow students and is further discussed.

Mind Maps can be designed using special software (fig. 1) as well as drawn by hand and uploaded to the system as a scan copy or photo (fig. 2).

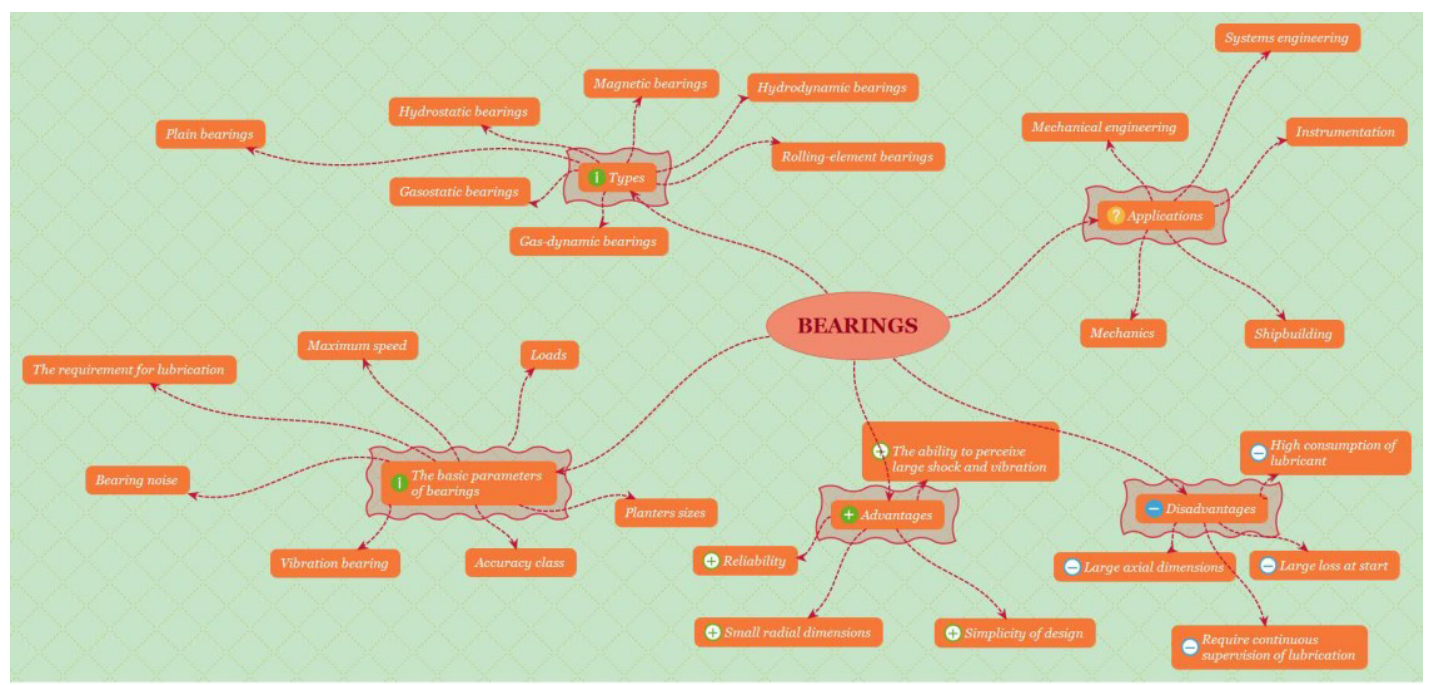

Figure 1. Mind map made by special program. 


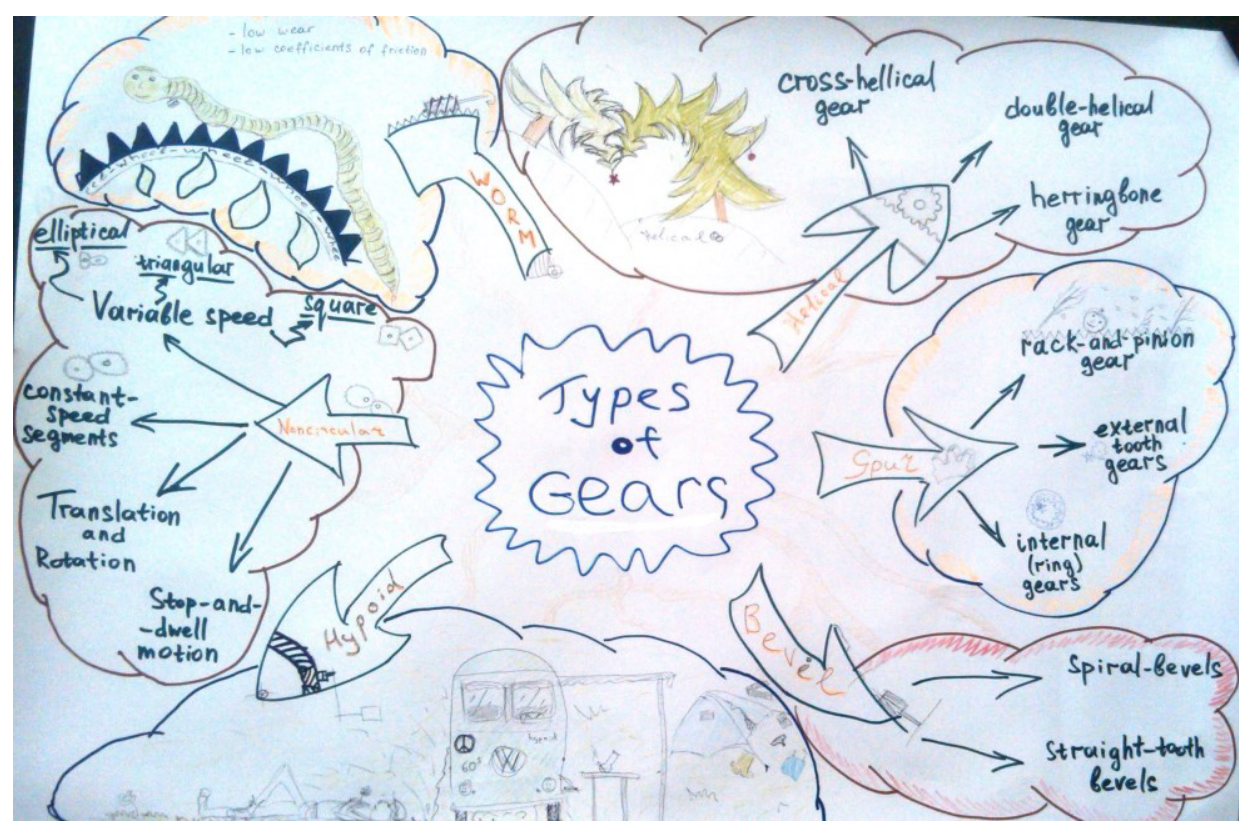

Figure 2. Hand-made Mind map.

The tool Forum can be used for organizing a group discussion. For example, in the course "Professional training in the English language" (module "Immediate problems of instrumentation engineering") the students were presented with 10 innovative solutions which, according to scientists, can improve the world. The students were allocated the task of choosing the three most important solutions from every student's point of view, discuss them with their fellow students and make a choice of the three most important solutions in the opinion of the whole group. It should be noted that, at the first glance, the easy task turned out to be quite difficult for accomplishing among Master's Degree students. Moreover, at the same time the similar task was allocated to the students during "face to face" classes (with the teacher present in the class). For an hour and a half this group could not arrive at a common view. In e-learning environment, the group of 12 students could not reach common ground as well. However, such a result of solving tasks is not a problem of working in elearning environment and on-line communication as it identifies the necessity of developing students' communication skills.

A suggestion about the development of a practice-based approach concerns the introduction of electronic modules of the syllabus into technical programs of Bachelor, Master and Specialist's degrees. For example, in physics -solutions of equations, mathematic and physical modeling of processes; electronics - calculation of electric circuits, signal processing; in the design of devices and systems - 3D modeling of the aircraft structure, calculation of printed circuits, etc.

\subsection{The results of the survey conducted among TPU students and teaching staff}

In May-June 2015 TPU administration conducted a sociological survey. The purpose of the survey was to reveal the views of teachers about the use of TPU e-learning courses in the educational process. Ninety teachers of TPU were involved in the survey.

The results of the study showed that the attitude of respondents towards the use of e-learning courses in the educational process was generally positive. E-learning courses involve students in learning process and have a positive effect on their academic performance. "Test", "Task", "Glossary" and "Forum" were characterized as the most frequently used tools [7].

E-learning courses make the most sense being introduced in the curricula of Bachelor's and Master's degree programs $(95,6 \%)$, facilitate effective management of students' self-study work 
$90,0 \%$, additionally involve students into educational process $86,7 \%$ and have positive impact on students' performance $81,1 \%$.

The teachers believe that the students are provided with a constant access to the educational materials $(94,4 \%)$ and the possibility of obtaining additional bonuses $(75,6 \%)$; while performing some types of tasks, they do not treat it negatively $(71,1 \%)$ and understand the necessity of using elearning courses in the educational process. According to the obtained data, the most popular tools are "Test" 96,7\%, "Task" 83,3\%, "Glossary" 83,3\% and "Forum" 72,2\%.

More than one thirds of the respondents $(37,8 \%)$ believe that such type of students' interaction as mutual assessment of their works does not bring them any discomfort, while $27,8 \%$ treat such experience quite negatively. The rest part of the respondents $(34,4 \%)$ had some difficulty evaluating the process and expressing their opinion on this issue.

At the same time the survey of 268 TPU students was carried out. [8]

According to the students interviewed, the teachers interacted with them often within e-learning courses commenting on tasks that were performed in the classroom as well as assessing works submitted through LMS Moodle.

According to the students, the most useful features of e-learning is a constant access to learning materials/assignments, participation in online storage, assignments and the opportunity of asking their teacher questions at any time.

The majority of respondents indicate the potential of e-learning course directly for instruction and not for communication and interaction with their fellow students.

According to most students interviewed, e-learning course promotes preparation for the exam/test.

\section{Conclusion}

In the opinion of the majority of the teachers and students interviewed, the use of e-learning is advisable and will be designed both to boost learning motivation and student's performance as well as to facilitate more effective management of student's self-study work.

The objectives of active training in e-learning environment will not be achieved if joint activities and outcomes are not pre-planned.

It should be mentioned that along with knowledge obtained on professional topics the expertise and communication skills are developed as well.

\section{Acknowledgement}

This work is funded within the framework of realization of Strategic Programme on National Research Tomsk Polytechnic University Competitiveness Enhancement in the Group of Top Level World Research and Academic Institutions.

\section{References}

1. D. Benta, G. Bologa, I. Dzitac, PCS 31, 1170 (2014)

2. Valentina Caputi, Antonio Garrido, JNCA 53, 115 (2015)

4. 20 facts about e-learning. http://www.onlinecultus.com/20-facts-about-e-learning/ (2016)

5. Ecevit Zümrüt Sati, Dursun Faruk, DUJofSS 42, 349 (2014)

6. Nina Bencheva, NTTRU - 49 3.2, 63 (2010)

7. V. Ivanova, K. Mertins, EE 16, 98 (2014)

8. Mnenie prepodavatelei TPU ob ispol'zovanii ehlektronnyh kursov v uchebnom processe.

Informacionno-analiticheskaya zapiska po rezul'tatam sociologicheskogo issledovaniya (TPU 2015)

9. Mnenie studentov TPU ochnoj formy obucheniya ob ispol'zovanii ehlektronnyh kursov $v$ uchebnom processe. Informacionno-analiticheskaya zapiska po rezul'tatam sociologicheskogo issledovaniya (TPU 2015) 